\title{
An In-Silico Study: Interaction of BOR1-type Boron (B) Transporters with A Small Group of Functionally Unidentified Proteins Under Various Stresses in Potato (Solanum tuberosum)
}

\author{
Firat KURT ${ }^{*}$, Adnan AYDIN2* \\ ${ }^{1}$ Muş Alparslan University, Faculty of Applied Sciences, Department of Plant Production and Technologies, Muş, Turkey \\ ${ }^{2}$ Iğdır University, Faculty of Agriculture, Department of Agricultural Biotechnology, Iğdır, Turkey \\ ORCID ID: Firat KURT: https:/ / orcid.org/0000-0003-0172-1953; Adnan AYDIN: https:/ / orcid.org/0000-0002-8284-3751
}

\begin{abstract}
Received: 27.07 .2020
Accepted: 03.12.2020

Published online: 09.12.2020

Issue published: 31.12 .2020

Abstract: Boron (B) is an important micro element for plant metabolism. There are several transporters having a role in B transport in plants. In this study, BOR1-type B transporters in potato (Solanum tuberosum) was identified and characterized through bioinformatical approaches. The five out of 10 identified BOR1 transporters (StBOR1-2,4,5, and 10) were found in the transcriptomic data. The expression heat map and co-expression networks were constructed with these identified proteins. Results showed that these identified five transporters were expressed more under Benzothiadiazole (BTH) compared to other treatments. The co-expression networks of five B transporters, constructed using 24,950 genes at 0.99 correlation coefficient with expression threshold above one fold change, showed that three B transporters were co-expressed with three functionally unknown proteins and Heparanase 1, a defense protein against pathogens. Also, StBOR1-4 and StBOR1-8 were found to crosstalk with Heparanase 1, PGSC0003DMT400010798, and PGSC0003DMT400030256 proteins. Generally, StBOR1-8 appears to be a key player regulating B and plant signal and on the defense mechanism. The Gene Ontology (GO) analysis, conducted for prediction of molecular functions of B transporters, resulted in three different clusters. Similarity Network analysis showed that StBOR1-10 may be involved in more different biological processes compared to the rest of the studied StBOR1 transporters. The identified three unknown proteins interacting with BOR1-type transporters can be further investigated under biotic stress. Particularly, PGSC0003DMT400025924 gen may be a component of plant immunity system. Moreover, roles of three mentioned proteins in B uptake and accumulation mechanism can be considered for future research.
\end{abstract}

Keywords: BOR1-type transporters, Boron, P. infestans, $\beta$-Amino-n-butyric Acid (BABA), Benzothiadiazole (BTH).

Bilgisayar Ortamında Bir Çalışma: BOR1-tipi Bor (B) Taşıyıcılarının Patateste (Solanum tuberosum) Çeşitli Stresler Altında İşlevsel Olarak Tanımlanmamış Küçük Bir Protein Grubuyla Etkileşimi

Öz: Bor (B) bitki metabolizması için önemli bir mikroelementtir. Bitkilerde B taşınımında rol oynayan farklı taşıyıcılar bulunmaktadır. Bu çalışmada patates (Solanum tuberosum) bitkisindeki BOR1 tipi B taşıyıcıları biyoinformatiksel yaklaşımlarla belirlenmiş ve karakterize edilmiştirler. On BOR1 taşıyıcısından beş tanesi (StBOR1-2,4,5, ve 10) transkriptomik veri seti içerisinde bulunmuştur. Ekspresyon 1sı haritası ve ko-ekspresyon veri ağları belirlenen beş proteine göre yapılmıştır. Sonuç olarak, BOR1 transporter olarak belirlenen beş transporterın en fazla Benzothiadiazole (BTH) uygulamasında eksprese edildiği bulunmuştur. 24950 genin 0.99 korelasyon katsayısı ve bir kat ve üzeri eşik değeri dikkate alınarak oluşturulan beş BOR1 geninin, patojenlere karşı bir savunma proteini olan Heparanase 1 ve fonksiyonel olarak tanımı yapılmamış üç farklı genle koeksprese edildiği saptanmıştır. Aynı zamanda StBOR1-4 ve StBOR1-8'nin Heparanase 1, PGSC0003DMT400010798, ve PGSC0003DMT400030256 proteinleri ile çapraz iletişimi bulunmuştur. Genel olarak, StBOR1-8 B alımın, bitki sinyal ve savunma mekanizmasının düzenlenmesinde anahtar bir rol oynadığı görülmektedir. StBOR1 genlerinin moleküler fonksiyonlarına ışık tutmak için yapılan Gen Ontolojisi (GO) analizine göre üç farklı demet meydana gelmiştir. Benzerlik ağı analizine göre StBOR1-10' un, bu çalışmada incelenen diğer StBOR1 genelerine göre çok daha farklı biyolojik proseslerde yer alabileceği görülmüş̧ür. Bu çalışmada StBOR1 taşıyıcıları ile etkileşen ve fonksiyonu bilinmeyen üç proteinin biyotik stres altında incelenmesi ileriki çalışmalarda yapılabilir. Özellikle, PGSC0003DMT400025924 geni bitki bağışıklık sisteminin bir parçası olabilir. Ayrıca, bu proteinlerinin B alınımı ve depolanma mekanizmasındaki rolleri gelecek araştırmalarda ele alınabilir.

Anahtar kelimeler: BOR1 tipi taşıııılar, Bor, P. infestans, $\beta$-Amino-n-Butirik Asit (BABA), Benzotiyadiazol (BTH).

\section{Introduction}

As a micro element, boron (B) has diverse roles in plant metabolism. Signaling, tensile strength and porosity of cell wall, cell wall synthesis, membrane integrity and function, polymerization of cytoskeleton, nitrogen assimilation mechanism, and regulation of amount and type of phenolic compounds cannot be maintained without B ( $\mathrm{Yu}$, Baluška, Jasper, Menzel, \& Goldbach, 2003; Ozyigit, Filiz, Saracoglu, \& Karadeniz, 2020). The uptake of B in plants takes place as boric acid $\mathrm{B}(\mathrm{OH})_{3}$. Boric acid is a small, relatively soluble compound which can permeate from plant cell membranes comparatively. The range of toxicity and deficiency levels of $B$ is very narrow compared to the other plant micro nutrients. Therefore, when B is sufficient for plant uptake, it is generally transported into root cells by passive transport. However, when soil B levels are below sufficient levels, then B uptake is mediated via two B transporter families: major intrinsic protein (MIP) and BOR family of borate $\left(\mathrm{B}(\mathrm{OH})_{4} 4^{-}\right.$(Yoshinari \& Takano, 2017)

It is reported that there are seven BOR1 genes in

*Corresponding authors: firat.kurt.usa@gmail.com, aydinadnann@gmail.com 
Arabidopsis (AtBOR1-7) belonging to prototype of clade I. The plants' organs where AtBOR1 is upregulated are roots, hypocotyls, and cotyledons. Primarily root tip cells followed by relatively epidermal, endodermal, and provascular cells are plant organs where AtBOR1 is highly expressed. It is suggested that the B uptake in cotyledons is associated with AtBOR1 expression in epidermal layer of cotyledon. (Yoshinari \& Takano, 2017). BOR is defined as one of the members of the bicarbonate transporter superfamily (SLC4). BOR1 expression occurs in root and shoot; however, when boric acid concentrations increase, BOR1 expression decreases due to post-transcriptional modifications (Tanaka \& Fujiwara, 2008). BOR1 is also involved in xylem loading of boric acid borate (Reid, 2014). AtBOR1 and -AtBOR4 are identified as efflux transporters which have a role in regulating cellular $B$ homeostasis under B excess. The overexpression of efflux BOR transporters such as HvBOR2 and TaBOR2 decreases B concentrations in tissues of barley and wheat, respectively (Reid, 2014). The objective of this study is to identify BOR1-type B transporters in potato (Solanum tuberosum) and the co-expressed proteins under Phytophthora infestans, $\beta$-Amino-n-butyric Acid (BABA), and Benzothiadiazole (BTH) treatments using in silico methods. For this aim, after BOR1-type B transporters were identified and characterized using bioinformatics tools, the co-expression network of each BOR1-type B transporter in the study was constructed by using 24,950 genes of transcriptomic data. Also, the expression heatmaps of five identified BOR1 transporters were created in potato to determine if there is a similar expression pattern among these transporters.

\section{Material and Methods}

\subsection{Identification of BOR1-type Boron Transporters in} Potato

Boron transporters were searched on UniProt database (https://www.uniprot.org) (Consortium, 2019) and Q8VYR7 numbered B transporter protein (Boron transporter 1) was used as reference for Blast search against potato genome on Phytozome v12.1.6. (Goodstein et al., 2012). A total of ten B transporters were selected at a very strict benchmark $(\mathrm{E}=0)$. Protein lengths, chromosomal locations, exon numbers, and domain information of these proteins were retrieved from Phytozome. The sub-cellular locations of the proteins were predicted using CELLO2GO server (http://cello.life.nctu.edu.tw/cello2go/) (Yu et al., 2014). Isoelectric points were identified on ProtParam tool (https://web.expasy.org/protparam/) (Gasteiger et al., 2005).

2.2. Construction Expression Heatmap and Co-expression Networks of Boron Transporters

The transcriptomic dataset with approximately 39,000 genes, obtained from the study of Xu et al. (2011) who treated potato with Phytophthora infestans, $\beta$-Amino-nbutyric Acid (BABA) and Benzothiadiazole (BTH), was used for expression and co-expression analyses. For this aim, the raw data, deposited to the Gene Expression Omnibus database (Edgar et al., 2002) with GSE30615 number, were extracted and analyzed on Galaxy project (Afgan et al., 2016) server in 2016. The RNA-seq analyses were conducted with reference to the Tuxedo protocol (Trapnell et al., 2012) . Briefly, the reads were mapped to the potato genome using Bowtie and TopHat. The genomic data of the potato were retrieved from Solanum tuberosum V4.03 on Phytozome v12.1. Cufflinks and CuffmergeCuffcompare tools were used for transcriptome assembly for conditions and combination of assemblies into one single assembly, respectively. Cuffdiff tool was used for the calculation of gene expressions along with the identification of significantly changed gene expressions. The expression values of identified BOR1-type B transporters were used for construction of the heatmap. The heatmap was created using Python programming language (van Rossum \& Drake, 2009). Then, treatments having zero values for all columns were deleted from the dataset and 24,950 genes were analyzed with correlation analysis using Python programming language (van Rossum \& Drake, 2009). The resulting dataset was further filtered at 0.99 coefficient threshold to find the most correlated proteins for each BOR1 transporters. The result files were visualized on Cytoscape 3.8.0 (Shannon et al., 2003) and the proteins having one and higher fold change were selected to find out the most correlated genes.

\subsection{Gene Ontology (GO) and Annotation and Sequence Similarity Network (SSN) Analyses}

The Gene Ontology analyses were conducted to predict molecular functions of BOR1 transporters. The analyses $\begin{array}{llll}\text { were conducted using AgriGO2 v2.0 } & 0\end{array}$ (http://systemsbiology.cau.edu.cn/agriGOv2/) (Tian et al., 2017) and REVIGO servers (http://revigo.irb.hr) (Supek, Bošnjak, Škunca, \& Šmuc, 2011). In order to make a good prediction, top ten genes in each correlation table used for AgriGO2 analysis. The redundancy in the results were eliminated using REVIGO server. For this aim, the GO search results were supplied to the REVIGO server to reduce and visualize GO results. The molecular function of the results was visualized on Cytoscape 3.8.0 (Shannon et al., 2003). The gene annotation analysis was conducted for highly expressed genes in the united co-expression network using BioMart tool of Ensembl Plants (Kinsella et al., 2011). The functional prediction of transporters was conducted through Sequence Similarity Network (SSN) tool of Enzyme Function Initiative (Zallot, Oberg, \& Gerlt, 2019). To do this, the sequences of Bicarbonate $\left(\mathrm{HCO}_{3}\right)^{-}$ transporter family with the alignment score of 100 were used as parameter values. The search was resulted in 6035 unique proteins (nodes) with 4,642,678 edges. In this SSN, in which nine StBOR1 transporters were found, the genes associated with nine StBOR1 transporters were selected to create a sub-cluster for functional predictions of StBOR1 genes in potato at alignment score of $\geq 350$.

\section{Results and Discussion}

BOR1-type B transporters were selected based on very strict threshold $(E=0)$. The identified transporters and their properties are given in Table 1. Later, these transporters were searched within transcriptomic data of $\mathrm{Xu}$ et al. (2011). Only five out of ten transporters were identified within transcriptomic data. The BOR1 transporters in the study have 10,12 , and 13 exons. BOR1 transporters have generally 12 exons as stated by Ozyigit et al. (2020) and Takano et al. (2002). The sub-cellular locations of these transporters were predicted to be in plasma membrane (PM).

All proteins have Bicarbonate $\left(\mathrm{HCO}_{3}\right)^{-}$transporter 
family domain and located on chromosome 1, 3, 6, and 8 . The transporters have equal negative and positive charges ranging from neutral to basic $\mathrm{pH}$. The lengths of the proteins are between 518-720. Bicorbonate transporter family is of animal cell origin (Takano et al., 2002). Bor1 transporters are polar- localized in the plasma membrane to facilitate directional transport of B from root cells to stele (Takano et al., 2002; Yoshinari et al., 2012, 2019; Yoshinari \& Takano, 2017). Ozyigit et al. (2020) found that BOR1 transporters are members of bicarbonate transporter family with 649-737 amino acid long. Everything considered, subcellular location and protein domain information are the indicator properties of BOR1 transporters.

\subsection{The Expression of BOR1-type Transporters}

The expression BOR1-type transporters are given in Figure 1. The final four digits of $B$ transporters were used to represent genes. According to heatmap, benzothiadiazole triggered almost all B transporters' expressions except StBOR1-9 (-2.93). StBOR1-5 expression (2.49) was the highest under BTH treatment. Although StBOR1-8 and StBOR1-9 transporters were downregulated under $P$. infestans, it seems there is considerable effect of it over StBOR1 transporters. StBOR1 transporters generally downregulated under the BABA treatment. StBOR1-4 was found as one of significantly expressed 2034 transcripts by giving resistance to late blight under $P$. infestans in potato (Draffehn et al., 2013). Collectively, there is a dynamic regulation of BOR1 transporters under mentioned treatments.

3.2. The Co-expression Networks of BOR1-type Transporters under Phytophthora Infestans, BABA, and BTH Treatments

The gene annotation analysis of highly co-expressed genes with BOR1-type transporters showed that just one out of four genes was described (Table 2). Similarly, only one protein domain was associated with the known protein domains among the co-expressed genes. Protein domain information of PGSC0003DMT400025924 was found as thioredoxin and cysteine/histidine-rich C1 family on Phytozome v12.1.4. Proteins or enzymes having thioredoxin domain are generally involved in plant immunity mechanism. Thioredoxin is a protein superfamily involved in regulation of cysteine oxidation as cysteine reductases; thereby, regulate plant immunity responses as signaling molecules (Mata-Pérez \& Spoel, 2019). In this respect, it is reported that sugarcane mosaic virus (SCMV) was repressed by a prevalent atypical thioredoxin protein (Zmtrxh) in cytoplasm of maize cells. Moreover, the same protein bestows resistance to sugarcane against SCMV at early stages of the infection regardless of salicylic and jasmonic acid signaling pathways (Liu et al., 2017) .Similar to the thioredoxin, the proteins with cysteine/histidine-rich C1 (CHR-C1) domains are involved in intracellular signal transduction as well (Consortium et al., 2000). It is reported that CHR$C 1$ was upregulated under powdery mildew disease in a grapevine cultivar called Regent (Welter et al., 2017). Furthermore, CHR-C1 genes were reported to be downregulated by application of Cellulose Biosynthesis Inhibitors-18. CBIs are the name of a diverse group of chemicals used for disruption or modification of cellulose synthesis pathway (Mortaji, 2011). These evidences point out that it is likely PGSC0003DMT400025924 is regulated by plant immune mechanism.

PGSC0003DMT400063377 is annotated as Heparanase 1. Heparanase is one of the proteins established in the apoplastic fluid (AF) 23-33\% of which consists of pathogen related proteins (PR-proteins) such as chitinases, $\beta$-1,3-glucanases, and thaumatin-like proteins. These PRs are defined as glycoside hydrolases (GHs) which are associated with polysaccharide breakdown and modification of microbial cell wall components, restricting pathogen growth (Guerra-Guimarães et al., 2016). Moreover, as a peroxidase, it is involved in lignification, auxin catabolism, wound healing, and defense against pathogen infection. It is reported that Heparanase has a role in scavenging of hydrogen peroxide giving rise to synthesis of phenolic compounds which are used for fortification of cell wall (Delaunois et al., 2013).

Table 1. BOR1-type transporters found in potato genome and their properties.

\begin{tabular}{|c|c|c|c|c|c|c|c|}
\hline Phytozome Transcript ID & $\begin{array}{l}\text { Domain †† } \\
\text { Family }\end{array}$ & $\begin{array}{l}\text { Putative* }^{*} \\
\text { Gene } \\
\text { Name for BOR1 Homologs }\end{array}$ & $\begin{array}{l}\text { Exon } \\
\text { No }\end{array}$ & $\begin{array}{l}\text { Chr. } \\
\text { Loc. }\end{array}$ & $\begin{array}{l}\text { Protein } \\
\text { Length } \\
\text { (aa) }\end{array}$ & $p I^{* *}$ & $\mathrm{SL}^{* * *}$ \\
\hline$\overline{\text { PGSC0003DMT400013371† }}$ & PF00955 & StBOR1-1 & 12 & 1 & 685 & 8.51 & PM \\
\hline PGSC0003DMT400013372 & PF00955 & StBOR1-2 & 12 & 1 & 720 & 8.76 & PM \\
\hline PGSC0003DMT400046120† & PF00955 & StBOR1-3 & 12 & 1 & 712 & 8.76 & PM \\
\hline PGSC0003DMT400046121 & PF00955 & StBOR1-4 & 12 & 1 & 713 & 8.76 & PM \\
\hline PGSC0003DMT400014548 & PF00955 & StBOR1-5 & 13 & 3 & 673 & 7.19 & PM \\
\hline PGSC0003DMT400014549† & PF00955 & StBOR1-6 & 13 & 3 & 672 & 8.03 & PM \\
\hline PGSC0003DMT400069674 ${ }^{\dagger}$ & PF00955 & StBOR1-7 & 12 & 6 & 518 & 9.54 & PM \\
\hline PGSC0003DMT400069678 & PF00955 & StBOR1-8 & 12 & 6 & 715 & 8.97 & $\mathrm{PM}$ \\
\hline PGSC0003DMT400073484 & PF00955 & StBOR1-9 & 10 & 6 & 520 & 8.84 & PM \\
\hline PGSC0003DMT400074816† & PF00955 & StBOR1-10 & 13 & 8 & 656 & 6.77 & PM \\
\hline
\end{tabular}

$\dagger$ These genes were not found in the expression dataset, $\uparrow \nmid \mathrm{PF} 00955$ : Bicarbonate $\left(\mathrm{HCO}_{3}\right)^{-}$transporter family, *The proteins were named based on their chromosomal location, **Isoelectric point, ${ }^{* *}$ Sub-cellular Location

Table 2. The highly co-expressed genes with StBOR1-2, StBOR1-4, and StBOR1-8 according to $\mathrm{r}=0.99$, and one and higher fold change benchmark.

\begin{tabular}{llll}
\hline Transcript ID & Gene Description & Protein Length & Protein Domain \\
\hline PGSC0003DMT400025924 & Conserved gene of unknown function & 309 & PTHR13871 $^{*}$ \\
PGSC0003DMT400063377 & Heparanase 1 & 83 & NF \\
PGSC0003DMT400010798 & Gene of unknown function & 100 & NF \\
PGSC0003DMT400030256 & Gene of unknown function & 59 & NF \\
\hline
\end{tabular}

*Thioredoxin, ${ }^{* *}$ Cysteine/Histidine-rich C1 domain family 


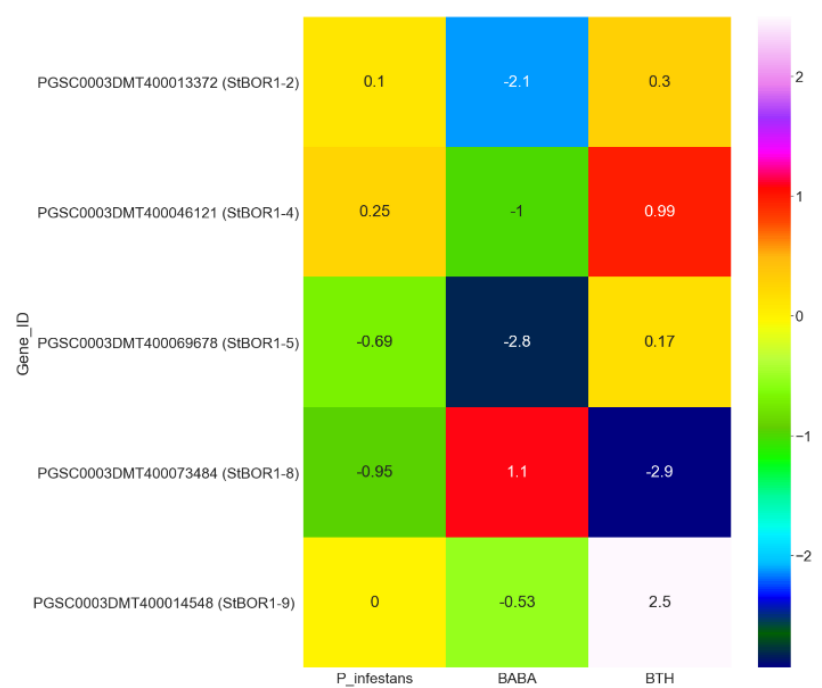

Figure 1. The expression values of StBOR1 transporters found in the dataset.

The united co-expression network of BOR1 transporters is given in Figure 2. As can be seen from Figure 2A, StBOR1-8 (red purple) interacts with genes in the cluster of StBOR1-4 (blue) and of StBOR1-2 (malachite). To find out if there is a cross-talk among coexpression networks and to identify highly correlated genes, the united co-expression network of $\mathrm{B}$ genes was filtered out using an additional benchmark. In this respect, genes in the network having one or higher expression levels were selected from the united co-expression network, constructed at 0.99 correlation coefficient. The results, given in Table 2 and Figure 2B, showed that there is a cross-talk between StBOR1-8 and StBOR1-4 with interaction of Heparanase 1 (PGSC0003DMT400063377) and PGSC0003DMT400010798. On the other hand, PGSC0003DMT400030256 was also found as interacting gene with StBOR1-8. Lastly, PGSC0003DMT400025924 was identified as the only gene interacting with StBOR1-2. As is known cell wall structure is affected by B deficiency. Dimerization of rhamnogalacturonan-II in borate is essential for normal function and shape of the cell wall (Noguchi et al., 2003). Therefore, it is possible there is likely to be an interaction among B transporters and genes involved in cell wall biosynthesis mechanism. Overall, some co-expressed genes with StBOR1 transporters may be involved in plant defense or immunity system.

3.2. The GO and SSN Analyses for Molecular Functions of BOR transporters

The result of GO analysis is displayed in Figure 3. Three different clusters occurred as a result of GO analysis. Active transmembrane transporter activity (TTA) inorganic anion TTA, anion TTA, and secondary active TTA were found connected. In the second cluster, nucleic acid binding, nucleoside phosphate binding, heterocylic binding, organic cyclic and transporter activity were found to be associated BOR1-type transporters in this study. As a last cluster, small molecule binding, oxidoreductase activity, DNA binding and nucleotide binding were identified as probable molecular functions of the studied B transporters. In nutshell, there seems to be functional clustering and divergence among BOR1 proteins.

The results of SSN analysis are given in Figure 4. Four StBOR1 transporters (1-2,1-4,1-8, and 1-10) were found in the sub-clusters of SSN network. Only two of 17 subclusters included StBOR1 transporters. StBOR1-10 transporter was distinctively different than all the other transporters. On the other hand, although there was not a clear separation of StBOR1-8 from StBOR1-2 and StBOR14; StBOR1-8 may be involved in more specific pathways in $B$ homeostasis. To conclude, there may be functional divergences among these proteins.

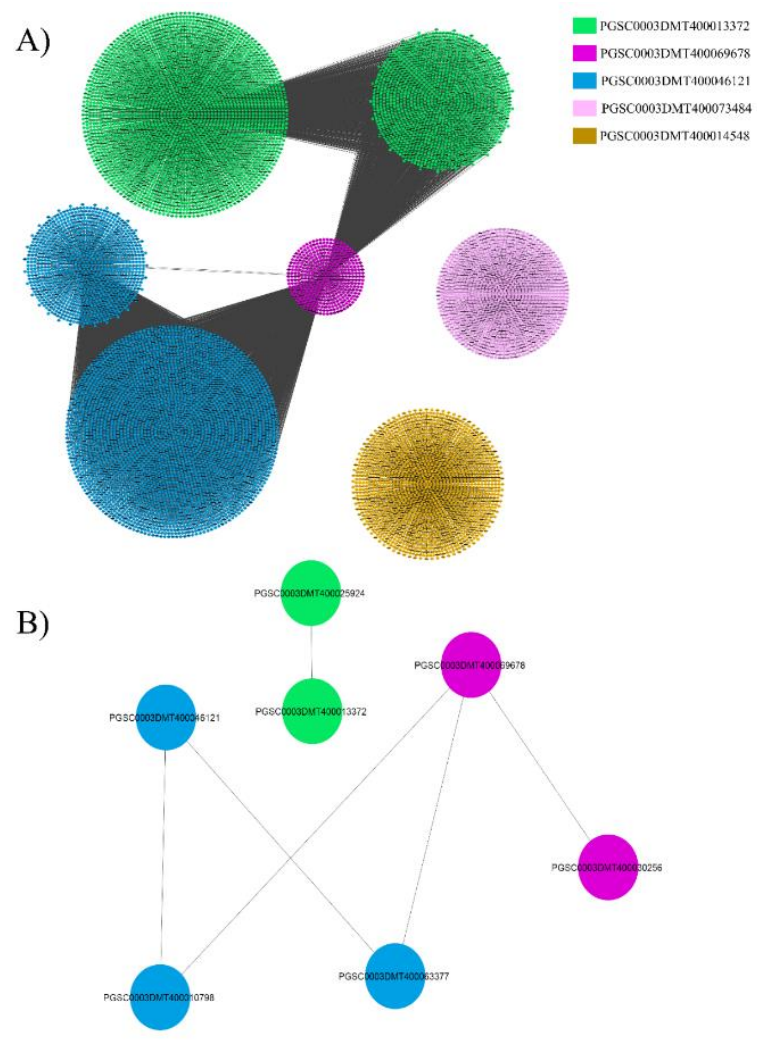

Figure 2. The united co-expression networks of StBOR1 transporters (A) and the most correlated genes above one and higher foldchanges (B). PGSC0003DMT400013372 (StBOR1-2), PGSC0003DMT400046121 (StBOR1-4), PGSC0003DMT400014548 (StBOR1-5), PGSC0003DMT400069678 (StBOR1-8), and PGSC0003DMT400073484 (StBOR1-9) were shown in different colors.

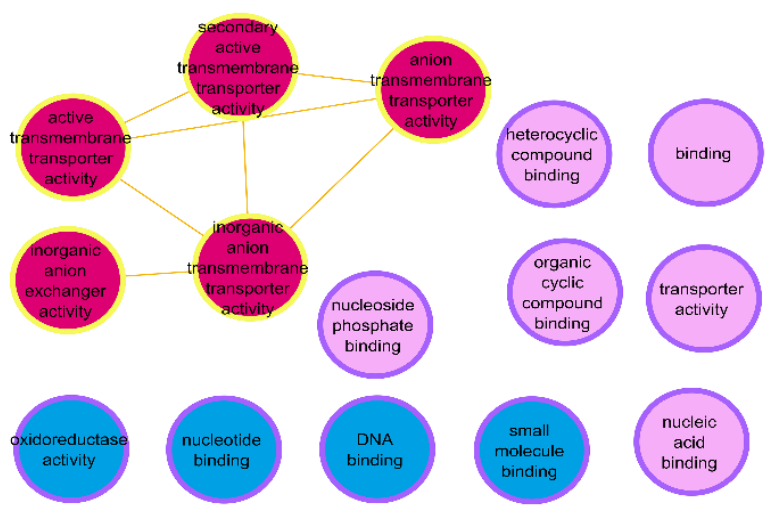

Figure 3. Gene ontology (GO) analysis of StBOR1transporters in terms of molecular function. Each cluster was shown in different color.

\section{Conclusion}

In this study, the BOR1-type transporters' expressions and co-expression interactions in potato were investigated. StBOR1 transporters seemed to be activated 
more by BTH compared to other treatments. Moreover, three functionally unknown proteins with Heparanase 1 were found to co-expressed with StBOR1-4 and StBOR1-8. These three proteins are relatively small proteins. StBOR18 was predicted to be a key BOR1 transporter in terms of its interactions in the united co-expression network and it may be involved in more diverse metabolic pathways in potato genome. Also, the identification of functionally unknown proteins under biotic stress and their associations with B uptake and accumulation mechanism should be considered for further research. a)

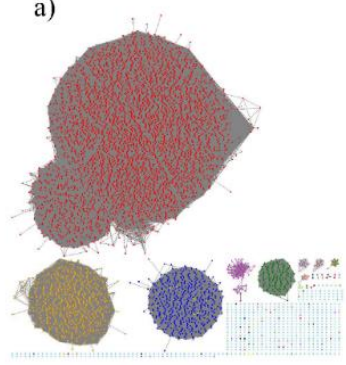

b)

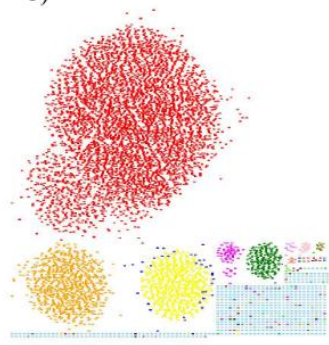

c)

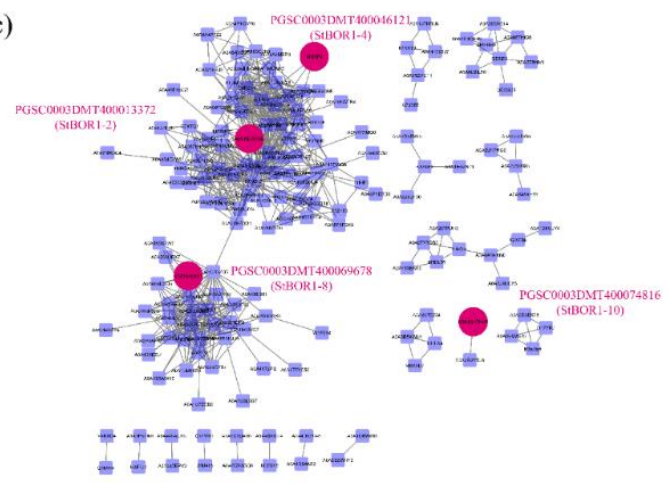

Figure 4. Sequence Similarity Network (SSN) of StBOR1 transporters. SSN was constructed based on the domain search of the Bicarbonate $\left(\mathrm{HCO}_{3}\right)^{-}$transporter family. The all SSN network (a) was generated with nine StBOR1 transporters. The selected genes associated with nine StBOR1 transporters (b) were used for the construction of 17 sub-clusters. To find out if there is a probable functional separation among nine StBOR1 nodes, a higher alignment score was used. The final sub-cluster of four StBOR1 transporters were shown in red purple (c).

\section{References}

Afgan, E., Baker, D., van den Beek, M., Blankenberg, D., Bouvier, D., Čech, M.,...\& Goecks, J. (2016). The Galaxy platform for accessible, reproducible and collaborative biomedical analyses: 2016 update. Nucleic Acids Research, 44, W3-W10. https://doi.org/10.1093/nar/ gkw343

Consortium EUC 3 AGS, Research TI for G, Institute KDNAR (2000). Sequence and analysis of chromosome 3 of the plant Arabidopsis thaliana. Nature, 408, 820-823. https://doi.org/10.1038/35048706

Consortium, T.U. (2019). UniProt: A worldwide hub of protein knowledge. Nucleic Acids Research, 47, D506-D515. https://doi.org/10.1093/nar/ gky1049

Delaunois, B., Colby, T., Belloy, N., Conreux, A., Harzen, A., Baillieul, F.,... \& Cordelier, S. (2013). Large-scale proteomic analysis of the grapevine leaf apoplastic fluid reveals mainly stress-related proteins and cell wall modifying enzymes. BMC Plant Biology, 13, 24. https://doi.org/10.1186 \1471-2229-13-24

Draffehn, A.M., Li, L., Krezdorn, N., Ding, J., Lübeck, J., Strahwald, J.,....\& Gebhardt, C. (2013). Comparative transcript profiling by SuperSAGE identifies novel candidate genes for controlling potato quantitative resistance to late blight not compromised by late maturity. Front Plant Science, 4, 1-21. https://doi.org/10.3389/fpls.2013.00423
Edgar, R., Domrachev, M., \& Lash, A.E. (2002). Gene Expression Omnibus: NCBI gene expression and hybridization array data repository. Nucleic Acids Research, 30, 207-210. https://doi.org/10.1093/nar/30.1.207

Gasteiger, E., Hoogland, C., Gattiker, A., Duvaud, S., Wilkins, M.r., Appel, R.D., \& Bairoch, A. (2005). Protein Identification and Analysis Tools on the ExPASy Server. In: Walker J.M. (eds) The Proteomics Protocols Handbook. Springer Protocols Handbooks. Humana Press. https://doi.org/10.1385/1-59259-890-0:571

Goodstein, D.M., Shu, S., Howson, R., Neupane, R., Hayes, R.D., Fazo, J., Mitros, T., Dirks, W., Hellsten, U., Putnam, N., \& Rokhsar, D.S. (2012). Phytozome: a comparative platform for green plant genomics. Nucleic Acids Research, 40(D1), D1178-D1186. https://doi.org/10.1093/nar/ gkr944

Guerra-Guimarães, L., Pinheiro, C., Chaves, I., Barros, D.R., \& Ricardo, C.P. (2016). Protein dynamics in the plant extracellular space. Proteomes, 4(22), 1-19. https://doi.org/10.3390/proteomes4030022

Kinsella, R.J., Kähäri, A., Haider, S., Zamora, J., Proctor, G., Spudich, G., Almeida-King, J., Staines, D., Derwent, P., Kerhornou, A., Kersey, P., \& Flicek, P. (2011). Ensembl BioMarts: A hub for data retrieval across taxonomic space. Database, 2011(bar030), 1-9. https://doi.org/10.1093/ database/bar030

Liu, Q., Liu, H., Gong, Y., Tao, Y., Jiang, L., Zuo, W.,...\& Xu, M. (2017). An Atypical Thioredoxin Imparts Early Resistance to Sugarcane Mosaic Virus in Maize. Molecular Plant, 10, 483-497. https://doi.org/10.1016/ j.molp.2017.02.002

Mata-Pérez, C., \& Spoel, S.H. (2019). Thioredoxin-mediated redox signalling in plant immunity. Plant Science, 279, 27-33. https://doi.org/10.1016/i.plantsci.2018.05.001

Mortaji, Z. (2011). Cellulose Biosynthesis Inhibitors Modulate Defense Transcripts and Regulate Genes that are Implicated in Cell Wall ReStructuring in Arabidopsis (M.Sc. Thesis), University of Ontario Institute of Technology, Canada.

Noguchi, K., Ishii, T., Matsunaga, T., Kakegawa, K., Hayashi, H., \& Fujiwara, T. (2003). Biochemical properties of the cell wall in the Arabidopsis mutant bor1-1 in relation to boron nutrition. Journal of Plant Nutrition and Soil Science, 166, 175-178. https://doi.org/10.1002/ jpln.200390025

Ozyigit, I.I., Filiz, E., Saracoglu, I.A., \& Karadeniz, S. (2020). Exploration of two major boron transport genes BOR1 and NIP5;1 in the genomes of different plants. Biotechnology \& Biotechnological Equipment, 34(1), 455468. https://doi.org/10.1080/13102818.2020.1773311

Reid, R. (2014). Understanding the boron transport network in plants. Plant Soil, 385, 1-13. https://doi.org/10.1007/s11104-014-2149-y

Shannon, P., Markiel, A., Ozier, O., Baliga, N. S., Wang, J.T., Ramage, D., Amin, N., Schwikowski, B., \& Ideker, T. (2003). Cytoscape: a software environment for integrated models of biomolecular interaction networks. Genome research, 13(11), 2498-2504. https://doi.org/10.1101/ gr.1239303

Supek, F., Bošnjak, M., Škunca, N., \& Šmuc, T. (2011). Revigo summarizes and visualizes long lists of gene ontology terms. Plos One, 6(7), e21800. https://doi.org/10.1371/journal.pone.0021800

Takano, J., Noguchi, K., Yasumori, M., Kobayashi, M., Gajdos, Z., Miwa, K., Hayashi, H., Yoneyama, T., \& Fujiwara, T. (2002). Arabidopsis boron transporter for xylem loading. Nature, 420(6913), 337-340. https://doi.org/10.1038/nature01139

Tanaka, M., \& Fujiwara, T. (2008). Physiological roles and transport mechanisms of boron: Perspectives from plants. Pflügers Archiv European Journal of Physiology, 456, 671-677. https://doi.org/10.1007/ s00424-007-0370-8

Tian, T., Liu, Y., Yan, H., You, Q., Yi, X., Du, Z., Xu, W., \& Su, Z. (2017). AgriGO v2.0: A GO analysis toolkit for the agricultural community, 2017 update. Nucleic Acids Research, 45(W1), W122-W129. https://doi.org/10.1093/nar/gkx382

Trapnell, C., Roberts, A., Goff, L., Pertea, G., Kim, D., Kelley, D.R.... \& Pachter, L. (2012). Differential gene and transcript expression analysis of RNA-seq experiments with TopHat and Cufflinks. Nature Protocols, 7, 562-578. https://doi.org/10.1038/nprot.2012.016

van Rossum, G., \& Drake, F.L. (2009). Python 3 Reference Manual. CreateSpace, Scotts Valley, CA

Welter, L.J., Tisch, C., Kortekamp, A., Töpfer, R., \& Zyprian, E. (2017) Powdery mildew responsive genes of resistant grapevine cultivar "regent." Vitis - Journal of Grapevine Research, 56, 181-188. https://doi.org/10.5073/vitis.2017.56.181-188

Xu, X., Pan, S., Cheng, S., Zhang, B., Mu, D., Ni, P., ..... \& Visser, R.G.F. (2011) Genome sequence and analysis of the tuber crop potato. Nature, 475, 189-195. https://doi.org/10.1038/nature10158 
Yoshinari, A., Kasai, K., Fujiwara, T., Naito, S., \& Takano, J. (2012). Polar localization and endocytic degradation of a boron transporter, BOR1, is dependent on specific tyrosine residues. Plant Signaling Behavior, 7, 4649. https://doi.org/10.4161/psb.7.1.18527

Yoshinari, A., \& Takano, J. (2017). Insights into the mechanisms underlying boron homeostasis in plants. Frontiers in Plant Science, 8(1951), 1-8. https://doi.org/10.3389/fpls.2017.01951

Yoshinari, A., Hosokawa, T., Amano, T., Beier, M.P., Kunieda, T., Shimada, T.... \& Takano, J. (2019). Polar localization of the borate exporter bor1 requires AP2-dependent endocytosis. Plant Physiology, 179, 1569-1580. https://doi.org/10.1104/pp.18.01017

Yu, C.S., Cheng, C.W., Su, W.C., Chang, K.C., Huang, S.W., Hwang, J.K., \& Lu, C.H. (2014). CELLO2GO: A web server for protein subcellular localization prediction with functional gene ontology annotation. Plos One, 9(6), e99368. https://doi.org/10.1371/journal.pone.0099368

Yu, Q., Baluška, F., Jasper, F., Menzel, D., \& Goldbach, H.E. (2003). Shortterm boron deprivation enhances levels of cytoskeletal proteins in maize, but not zucchini, root apices. Physiologia Plantarum, 117(2), 270278. https://doi.org/10.1034/j.1399-3054.2003.00029

Zallot, R., Oberg, N., \& Gerlt, J.A. (2019). The EFI Web Resource for Genomic Enzymology Tools: Leveraging Protein, Genome, and Metagenome Databases to Discover Novel Enzymes and Metabolic Pathways. Biochemistry, 58(41), 4169-4182. https://doi.org/10.1021/ acs.biochem. $9 \mathrm{~b} 00735$ 